\title{
Proses Pemberdayaan Masyarakat Melalui Gerakan Pemberdayaan dan Kesejahteraan Keluarga (PKK) di Kabupaten Subang
}

\section{Tony Pathony}

Fakultas Ilmu Administrasi, Universitas Subang

tonypathony.jurnal@gmail.com

\begin{abstract}
Abstrak
Tujuan dari penelitian ini adalah untuk mengetahui proses pemberdayaan masyarakat melalui pemberdayaan dan Gerakan Kesejahteraan Keluarga Di Subang. Penelitian dan penulisan itu membahas hal-hal yang berkaitan dengan bagaimana proses pemberdayaan masyarakat melalui pemberdayaan dan Gerakan Kesejahteraan Keluarga di Kabupaten Subang sesuai dengan teori-teori yang diungkapkan oleh Edi Suharto yaitu Pemungkinan, Penguatan, Perlindungan, Penyokongan, Pemeliharaan. Dalam penelitian ini menggunakan pendekatan kualitatif dengan penelitian yang bersifat deskriptif, karena penelitian ini bertujuan untuk memperoleh gambaran yang lebih besar digunakan untuk mengungkapkan masalah dalam kehidupan kerja pengamatan organisasi pemerintah, wawancara, studi kepustakawanan dan dokumentasi. Tidak ada pilihan lain selain menjadikan para peneliti itu sendiri sebagai instrumen para peneliti utama. Sumber data diperoleh dari informan melalui pengamatan langsung dan wawancara serta dokumen yang diperoleh dalam bentuk aturan dan pengolahan data. Hasil penelitian menunjukkan bahwa proses pemberdayaan masyarakat melalui pemberdayaan dan gerakan kesejahteraan keluarga sesuai dengan teori Pemberdayaan sebagai proses yang dikemukakan oleh Edi Suharto yaitu Proses pemberdayaan masyarakat melalui gerakan Keluarga Sejahtera dan Pemberdayaan di Kabupaten Subang belum optimal. Kesimpulan temuan di lapangan yaitu Pemungkinan, Penguatan, Perlindungan, Penyokongan, Pemeliharaan belum dinilai sesuai dengan teori yang digunakan.
\end{abstract}

Kata kunci : pemberdayaan, masyarakat, komunitas

\section{Abstract}

The purpose of this research is to know the process of community empowerment through empowerment and the family welfare Movement In Subang. Research and writing of it 
discusses matters related to how the process of community empowerment through empowerment and family welfare Movement in the Regency of Subang in accordance with the theories expressed by Edi Suharto i.e. Pemungkinan, Penguatan, Perlindungan, Penyokongan, Pemeliharaan. In this study using a qualitative approach to research that is descriptive, because this study aims to gain a bigger picture examined used to reveal problems in working life government organizations observations, interviews, the study of librarianship and documentation. There is no other option than to make the researchers themselves as instruments of the major researchers. Source data obtained from the informants through direct observations and interviews and documents obtained in the form of rules and data processing. Results of the study showed that the process of community empowerment through empowerment and family welfare Movement in accordance with the theory of Empowerment as the process advanced by Edi Suharto i.e. community empowerment Process through Family welfare and Empowerment movement in the Regency of Subang has not been optimal. Conclusion the findings in the field namely Pemungkinan, Penguatan, Perlindungan, Penyokongan, Pemeliharaan has not been assessed in accordance with the theory used.

Keywords : empowerment, welfare, community

\section{Pendahuluan}

Pembangunan Nasional bertujuan untuk mewujudkan masyarakat Indonesia yang adil dan makmur, merata, materil, spiritual, melalui peningkatan taraf hidup masyarakat, kecerdasan dan kesejahteraan rakyat. Pembangunan tersebut diharapkan dapat dilaksanakan secara merata bagi seluruh rakyat. Pembangunan akan berjalan secara optimal apabila ditunjang oleh sumber daya manusia yang baik, dengan memiliki Indikator Pembangunan Manusia atau Human Development Index (HDI) yang tinggi. Mensejahterakan masyarakat dalam segala bidang adalah salah satu cita-cita pemerintah. Tetapi banyak kendala untuk mewujudkannya sehingga harapan pemerintah untuk menciptakan kemandirian masyarakat sulit tercapai. Permasalahan dalam kesejahteraan keluarga yaitu Pendidikan, Kesehatan, Sosial Budaya, Lingkungan, Ekonomi, dan Hukum

Kemandirian masyarakat adalah wujud dari pengembangan kemampuan ekonomi daerah untuk menciptakan kesejahteraan dan memperbaiki material secara adil dan merata yang ujungnya berpangkal pada pemberdayaan masyarakat. Pemberdayaan masyarakat sendiri berdiri pada satu pemikiran bahwa pembangunan akan berjalan dengan sendirinya apabila masyarakat diberi hak mengelola sumberdaya alam yang mereka miliki dan menggunakannya untuk pembangunan masyarakatnya (Sutrisno, 1995). Proses Pemberdayaan merupakan upaya yang disengaja untuk memfasilitasi masyarakat lokal dalam merencanakan, memutuskan dan mengelola sumberdaya lokal yang dimiliki sehingga pada akhirnya mereka memiliki kemampuan dan kemandirian secara ekonomi, ekologi dan sosial (Subejo dan Narimo, 2004). Melalui Pemberdayaan Masyarakat, masyarakat harus mampu mengatasi masalah-masalah yang dihadapi dengan upaya sendiri, serta mampu mengembangkan kreativitas untuk memanfaatkan setiap 
potensi dan peluang untuk dapat memperbaiki mutu hidupnya dalam membangun diri dan lingkungannya.

Gerakan Pemberdayaan dan Kesejahteraan Keluarga (PKK) sebagai mitra pemerintah mempunyai tugas untuk pemenuhan kebutuhan dasar sehingga terwujudnya pemberdayaan dan kesejahteraan keluarga. TP.PKK bertugas untuk merangkul dan membina masyarakat, sehingga semua kalangan masyarakat dapat merasakan hasil dari pembangunan. Gerakan PKK mendukung program-program pemerintah melalui 10 Program pokok PKK. Pemberdayaan Masyarakat melalui Gerakan Pemberdayaan dan Kesejahteraan Keluarga (PKK) menurut Peraturan Menteri Dalam Negeri Republik Indonesia Nomor 1 Tahun 2013 yaitu upaya untuk memandirikan masyarakat dan bertujuan untuk meningkatkan kesejahteraan menuju terwujudnya keluarga yang beriman dan bertaqwa kepada Tuhan Yang Maha Esa, berakhlak mulia dan berbudi luhur, sehat sejahtera, maju dan mandiri, kesataraan dan keadilan gender serta kesadaran hukum dan lingkungan.

Menurut data Badan Pusat Statistik, Kabupaten Subang memiliki jumlah penduduk sebanyak 1.562.509 Jiwa dengan komposisi penduduk laki-laki berjumlah 789.211 Jiwa dan penduduk perempuan berjumlah 773.298 Jiwa. Jumlah Penduduk Usia Kerja sebanyak 1.191.759 Jiwa, ada sebanyak 398.093 jiwa yang termasuk bukan angkatan kerja dan ada sebanyak 69.358 jiwa yang pengangguran. Masih banyak masyarakat yang belum bisa menggali potensi yang ada didalam dirinya dan dilingkungannya, mereka belum bisa berinovasi dan berexperimen untuk menambah penghasilannya sehingga mereka bisa hidup sejahtera. Karena menurut data klasifikas di Kabupaten Subang, setiap tahun jumlah Keluarga Pra Sejahtera selalu beranjak naik. Sekarang memasuki Generasi Millennial yang sudah mengenal teknologi canggih dan berinovatif, sehingga masyarakat dengan mudah mengakses informasi yang ada diluar. Tetapi efek Negatifnya dijaman modern ini yaitu semakin banyak kasus yang timbul seperti Pembunuhan, Pencurian, Penculikan, KDRT, Narkoba, Bunuh Diri, Trafficking, dan sebagainya. Kekerasan kepada perempuan dan anak terkadang selalu diakhiran dengan pembunuhan oleh orang terdekat. Berbagai penyakit baru pun mulai bermunculan seperti HIV, Stunting, berbagai macam Kanker dan lain sebagainya. Selain itu peredaran narkoba pun semakin merajalela dan beragam macamnya bentuknya dengan harga terjangkau dan dikonsumsi oleh berbagai kalangan, dari anak kecil sampai orang tua.

Kecamatan Subang adalah kecamatan yang paling terdekat dengan kabupaten. Kecamatan Subang memiliki 8 kelurahan dengan jumlah penduduk sebanyak 133.143 Jiwa dan jumlah KK sebanyak 35.376 KK. Menurut data Badan Pusat Statistik ada sebanyak 2.191 keluarga yang masuk dalam klasifikasi keluarga pra sejahtera di kecamatan Subang. Kecamatan Subang adalah kecamatan yang maju dan modern, tetapi dibalik semua itu banyak persoalan yang terjadi seperti Pergaulan bebas, sifat masyarakat yang sudah individualis sehingga tidak peduli sekitarnya, selain itu masalah perekonomian pun belum bisa berjalan dengan baik. Masyarakat sekitar belum bisa mengembangkan potensi yang ada didalam diri mereka, memanfaatkan limbah lingkungan dan belum bisa mengikuti perkembangan teknologi karena pengetahuan dan keterampilan yang mereka punya 
belum memadai. Memang sangat sulit untuk merubah pola pikir dan kebiasaan masyarakat. Karena jika sudah terbiasa maka akan sulit untuk berubah.

Disamping hasil observasi yang telah dilakukan, penulis menemukan permasalahan di lapangan yaitu masyarakat yang belum bisa mengembangkan potensi dalam dirinya secara optimal, berbagai kemungkinan keberhasilan dan kegagalan termasuk hambatan atau peluang dalam melaksanakan program ini, TP.PKK harus memikirkan secara matang untuk mewujudkan tercapainya program sehingga Proses Pemberdayaan Masyarakat melalui Gerakan Pemberdayaan dan Kesejahteraan Keluarga (PKK) di Kabupaten Subang belum berjalan dengan optimal, hal ini dapat dilihat dari indikator sebagai berikut:

1. Masyarakat banyak yang belum mengetahui pentingnya kegiatan-kegiatan yang disosialisasikan oleh Tim Penggerak Pemberdayaan dan Kesejahteraan Keluarga (TP.PKK) ?

2. Masyarakat belum bisa mengoptimalkan potensi di dalam dirinya dan potensi di sekitar lingkungannya?

3. Masih sedikit masyarakat yang mau terjun langsung untuk menjadi kader kegiatan Pemberdayaan dan Kesejahteraan Keluarga, dari data BPS kab.Subang pada tahun 2017, jumlah perempuan yg berusia 20 sampai 75+ tahun sebanyak 534.036 Jiwa, sedangkan jumlah kader umum pada tahun 2017 hanya 57.599 sehingga hanya $10 \%$ yang mau menjadi kader dan hampir kebanyakan adalah ibu-ibu yang sudah berumur.

Berdasarkan latar belakang masalah diatas maka penulis tertarik untuk melakukan penelitian selanjutnya akan penulis pecahkan permasalahannya dalam bentuk Skripsi dengan Judul "Proses Pemberdayaan Masyarakat Melalui Gerakan Pemberdayaan dan Kesejahteraan Keluarga (PKK) di Kabupaten Subang“.

Adapun kerangka teorinya dapat penulis kemukakan sebagai berikut : Gerakan Pemberdayaan dan Kesejahteraan Keluarga (PKK) merupakan bentuk layanan pemerintah yang bertujuan mensejahterakan masyarakat. Pelatihan dan sosialisasi yang diadakan oleh pengurus TP.PKK Kabupaten Subang, semuanya bertujuan agar dapat diterapkan dalam kehidupan sehari hari setelah mengikuti pelatihan keterampilan masyarakat dapat meningkatkan potensi dan perekonomian masyarakat.

Untuk mengetahui bagaimana Proses Pemberdayaan Masyarakat Melalui Gerakan Pemberdayaan dan Kesejahteraan Keluarga (PKK), peneliti akan menggunakan pendekatan pemberdayaan menurut Suharto (1997) yang disingkat menjadi 5 P yaitu Pemungkinan, Penguatan, Perlindungan, Penyokongan, Pemeliharaan. Karena ada keterkaitan satu sama lainnya dengan permasalahan yang peneliti temukan.

\section{Kerangka Teori}

\section{Konsep Pemberdayaan}

Pemberdayaan sebagai sebuah proses perubahan kemudian memiliki konsep yang bermakna. Proses pemberdayaan sangat tergantung pada dua hal yaitu: 
1. Bahwa kekuasaan dapat berubah. Jika kekuasaan tidak dapat berubah, pemberdayaan tidak mungkin terjadi dengan cara apapun

2. Bahwa kekuasaan dapar diperluas. Konsep ini menekankan pada pengertian kekuasaan yang tidak statis, melainkan dinamis.

Menurut Kartasasmita dalam Totok dan Soebianto (2015:53) mendefinisikan bahwa pemberdayaan adalah upaya untuk membangun daya itu sendiri, dengan mendorong, memotivasi dan membangkitkan kesadaran akan potensi yang dimilikinya serta berupaya untuk mengembangkannya. Selanjutnya, upaya tersebut diikuti dengan memperkuat potensi atau daya yang dimiliki oleh masyarakat itu sendiri. Sumodiningrat dalam Mardikanto dan Soebianto (2015:33) juga berpendapat bahwa pemberdayaan merupakan upaya pemberian kesempatan dan atau memfasilitasi kelompok miskin agar mereka memiliki aksesibilitas terhadap sumberdaya, yang berupa modal, teknologi, informasi, jaminan pemasaran dan lainlain agar mereka mampu memajukan dan mengembangkan usahanya, sehingga memperoleh perbaikan pendapatan serta perluasan kesempatan kerja demi perbaikan kehidupan dan kesejahteraannya. Dengan demikian, Pemberdayaan menurut Suharto (2005:59-60) adalah sebuah proses dan tujuan. Sebagai Proses, pemberdayaan adalah serangkaian kegiatan untuk memperkuat kekuasaan atau keberdayaan kelompok lemah dalam masyarakat, termasuk individu-individu yang mengalami masalah kemiskinan. Sebagai Tujuan, maka pemberdayaan menunjuk pada keadaan atau hasil yang ingin dicapai oleh sebuah perubahan sosial yaitu masyarakat yang berdaya, memiliki kekuasaan atau mempunyai pengetahuan dan kemampuan dalam memenuhi kebutuhan hidupnya baik yang bersifat fisik, ekonomi maupun sosial seperti memiliki kepercayaan diri, mampu menyampaikan aspirasi, mempunyai mata pencaharian, berpartisipasi dalam kegiatan sosial dan mandiri dalam melaksanakan tugas-tugas kehidupannya (Widiyanto, Hikmawan, \& Riswanda, 2019).

\section{Konsep Masyarakat}

Menurut Koenjaraningrat (2012: 122) yaitu masyarakat merupakan kesatuan hidup manusia yang berinteraksi sesuai dengan sistem adat-istiadat tertentu yang sifatnya berkesinambungan dan terikat oleh suatu rasa identitas bersama. Menurut J.L. Gilin dan J.P. Gilin dalam Syani (2012:32), masyarakat merupakan kelompok manusia yang terbesar dan mempunyai kebiasaan, tradisi, sikap, dan persatuan yang sama. Menurut Soekanto (2012: 32), ciri-ciri dari masyarakat yaitu: 1) Masyarakat merupakan manusia yang hidup bersama; 2) Bercampur untuk waktu yang cukup lama; 3) Mereka sadar bahwa mereka merupakan suatu kesatuan, 4) Mereka merupakan suatu sistem hidup bersama. Berdasarkan pengertian dan ciriciri masyarakat yang dikemukakan para ahli di atas dapat di simpulkan bahwa masyarakat merupakan sekumpulan manusia (individu) yang bertempat tinggal di wilayah tertentu dimana saling berinteraksi dalam kehidupan sosialnya (Hikmawan, 2017a), berkumpul dan saling ketergatungan antara individu satu dan individu lainnya 


\section{Konsep Pemberdayaan Masyarakat}

Mardikanto dan Soebianto (2015:30) menjelaskan bahwa pemberdayaan masyarakat merupakan upaya untuk meningkatkan harkat dan martabat lapisan masyarakat yang dalam kondisi sekarang tidak mampu untuk melepaskan diri dari perangkap kemiskinan dan keterbelakangan. Dengan kata lain, pemberdayaan adalah memampukan dan memandirikan masyarakat. Mardikanto dan Soebianto (2015:61) juga berpendapat bahwa pemberdayaan masyarakat adalah suatu proses dimana masyarakat, terutama mereka yang miskin sumber daya, kaum perempuan dan kelompok yang terabaikan lainnya, didukung agar mampu meningkatkan kesejahteraannya secara mandiri. Maka dapat disimpulkan bahwa pemberdayaan masyarakat adalah upaya untuk memberikan daya (empowerment) atau penguatan (strengthening) kepada masyarakat, terutama mereka yang miskin sumber daya, kaum perempuan dan kelompok yang terabaikan lainnya dengan mendorong, memotivasi, dan memfasilitasi untuk mengembangkan potensi yang dimilikinya agar mampu melepaskan diri dari kemiskinan dan meningkatkan kesejahteraannya secara mandiri (Hikmawan, 2017b). Tujuan Pemberdayaan menurut Mardikanto (2002) meliputi beragam upaya perbaikan sebagai berikut :

\section{Perbaikan Pendidikan}

Pemberdayaan harus dirancang sebagai suatu bentuk pendidikan yang lebih baik, perbaikan pendidikan yang mampu menumbuhkan semangat belajar seumur hidup

2. Perbaikan Aksesibilitas

Dengan tumbuh dan berkembangnya semangat belajar seumur hidup, diharapkan akan memperbaiki aksesibilitasnya dengan sumber informasi / inovasi

3. Perbaikan Tindakan

Dengan perbaikan pendidikan dan perbaikan aksesibilitas dengan beragam sumberdaya yang lebih baik, diharapkan akan terjadi tindakan-tindakan yang semakin lebih baik

4. Perbaikan Kelembagaan

Dengan perbaikan kegiatan / tindakan yang dilakukan, diharapkan akan memperbaiki kelembagaan, termasuk pengembangan jejaring kemitraan usaha

5. Perbaikan Usaha

Perbaikan Pendidikan, Perbaikan Aksesibilitas, Perbaikan Tindakan dan Perbaikan Kelembagaan, diharapkan akan memperbaiki bisnis yang dilakukan

6. Perbaikan Pendapatan

Dengan terjadinya perbaikan bisnis yang dilakukan, diharapkan akan dapat memperbaiki pendapatan yang diperolehnya, termasuk pendapatan keluarga dan masyarakatnya

7. Perbaikan Lingkungan

Perbaikan pendapatan diharapkan dapat memperbaiki lingkungan (Fisik dan Sosial), karena kerusakan lingkungan seringkali disebabkan oleh kemiskinan atau pendapatan yang terbatas

8. Perbaikan Kehidupan 
Tingkat pendapatan dan keadaan lingkungan yang membaik, diharapkan dapat memperbaiki keadaan kehidupan setiap keluarga dan masyarakat

9. Perbaikan Masyarakat

Keadaan kehidupan yang lebih baik, yang didukung oleh lingkungan (Fisik dan Sosial) yang lebih baik, diharapkan akan terwujud kehidupan masyarakat yang lebih baik pula

Menurut Kieffer (1981), Pemberdayaan mencakup tiga dimensi yang meliputi Kompetensi Kerakyatan, Kemampuan Sosiopolitik dan Kompetensi Partisipatif (Suharto, 1997:215). Schuler, Hashemi dan Riley mengembangkan delapan indikator pemberdayaan, yang disebut indeks pemberdayaan (Suharto,2004) yaitu

1. Kebebasan Mobilitas

Kemampuan individu untuk pergi ke luar rumah atau wilayah tempat tinggalnya.

2. Kemampuan membeli komoditas kecil

Kemampuan individu untuk membeli barang-barang kebutuhan keluarga seharihari.

3. Kemampuan membeli komoditas besar

Kemampuan individu untuk membeli barang-barang sekunder atau tersier

4. Terlibat dalam pembuatan keputusan-keputusan rumah tangga

Mampu membuat keputusan secara sendiri maupun bersama pasangan mengenai keputusan-keputusan keluarga

5. Kebebasan relatif dari dominasi keluarga

Responden ditanya mengenai apakah dalam satu terakhir ada keluarga yang mengambil uang, tanah, perhiasan dari dia tanpa ijinnya

6. Kesadaran hukum dan politik

Mengetahui pentingnya memiliki dokumentasi diri, memiliki surat nikah dan mengetahui hukum-hukum waris

7. Keterlibatan dalam kampanye dan protes-protes

Seseorang dianggap "berdaya" jika ia pernah terlibat dalam kampanye melakukan protes

8. Jumlah ekonomi dan kontribusi terhadap keluarga

Memiliki rumah, tanah, asset produktif, tabungan. Seseorang dianggap memiliki poin tinggi jika ia memiliki aspek-aspek tersebut.

Keberhasilan pemberdayaan masyarakat dapat dilihat dari keberdayaan mereka yang menyangkut kemampuan ekonomi, kemampuan mengakses manfaat kesejahteraan dan kemampuan kultural dan politis. Ketiga aspek tersebut dikaitkan dengan empat dimensi kekuasaan, yaitu :

1. Kekuasaan di dalam

2. Kekuasaan untuk

3. Kekuasaan atas

4. Kekuasaan dengan

Lingkup kegiatan pemberdayaan masyarakat menurut Mardikanto dan Soebianto (2015:114) antara lain: 
a. Bina Manusia

Menurut Mardikanto dan Soebianto (2015:114), bina manusia merupakan upaya yang pertama dan utama yang harus diperhatikan dalam setiap upaya pemberdayaan masyarakat. Hal ini dilandasi oleh pemahaman bahwa tujuan pembangunan adalah untuk perbaikan mutu hidup atau kesejahteraan manusia. Disamping itu dalam ilmu manajemen, manusia menempati unsur yang paling unik karena selain sebagai salah satu sumberdaya juga sekaligus pelaku atau pengelola manajemen itu sendiri. Upaya bina manusia adalah semua kegiatan yang termasuk dalam upaya penguatan atau pengembangan kapasitas yang meliputi:

1) Pengembangan kapasitas individu, yang meliputi kapasitas kepribadian, kapasitas di dunia kerja dan pengembangan keprofesionalan.

2) Pengembangan kapasitas entitas/kelembagaan yang meliputi:

i. Kejelasan visi, misi dan budaya organisasi

ii.Kejelasan struktur organisasi, kompetensi dan strategi organisasi

iii.Proses organisasi atau pengelolaan organisasi

iv.Pengembangan jumlah dan mutu sumberdaya

v. Interaksi antar individu di dalam organisasi

vi.Interaksi dengan entitas organisasi dengan pemangku kepentingan (stakeholder) yang lain.

3) Pengembangan kapasitas sistem (jejaring) yang meliputi:

i. Pengembangan interaksi antar entitas (organisasi) dalam system yang sama

ii. Pengembangan interaksi dengan entitas/organisasi di luar sistem

b. Bina Usaha

Bina usaha menjadi suatu upaya penting dalam setiap pemberdayaan, sebab bina manusia yang tanpa memberikan dampak atau manfaat bagi perbaikan kesejahteraan (ekonomi) tidak akan laku dan bahkan menambah kekecewaan. Sebaliknya, hanya bina manusia yang mampu (dalam waktu dekat/cepat) memberikan dampak atau manfaat bagi perbaikan kesejahteraan (ekonomi) yang akan laku atau memperoleh dukungan dalam bentuk partisipasi masyarakat. Bina usaha mencakup:

1) Pemilihan komoditas dan jenis usaha

2) Studi kelayakan dan perencanaan bisnis

3) Pembentukan badan usaha

4) Perencanaan investasi dan penetapan sumber-sumber pembiayaan

5) Pengelolaan SDM dan pengembangan karir

6) Manajemen produksi dan operasional

7) Manajemen logistic dan finansial

8) Penelitian dan pengembangan

9) Pengembangan dan pengelolaan sistem informasi bisnis

10) Pengembangan jejaring dan kemitraan

11) Pengembangan sarana dan prasarana pendukung

c. Bina Lingkungan

Sejak dikembangkan mahzab pembangunan berkelanjutan (sustainable development), isu lingkungan menjadi sangat penting. Karena pelestarian lingkungan akan sangat menentukan keberlanjutan kegiatan investasi maupun 
operasi (utamanya yang terkait dengan tersedianya bahan baku). Selama ini pengertian lingkungan seringkali dimaknai sekedar lingkungan fisik, utamanya yang menyangkut pelestarian sumberdaya alam dan lingkungan hidup. yang termasuk tanggungjawab lingkungan adalah kewajiban dipenuhinya segala kewajiban yang ditetapkan dalam persyaratan investasi dan operasi yang terkait dengan perlindungan, pelestarian dan pemulihan (rehabilitasi/reklamasi) sumberdaya alam dan lingkungan hidup.

d. Bina Kelembagaan

Tersedianya dan efektivitas kelembagaan akan sangat berpengaruh terhadap keberhasilan bina manusia, bina usaha dan bina lingkungan. Pengertian tentang kelembagaan seringkali dimaknai dalam arti sempit sebagai beragam bentuk lembaga (kelompok, organisasi). tetapi kelembagaan sebenarnya memiliki arti yang lebih luas. Hayami dan Kikuchi (dalam Mardikanto dan Soebianto, 2015:116) mengartikan kelembagaan sebagai suatu perangkat umum yang ditaati oleh anggota suatu komunitas (masyarakat)

Wilson (dalam Mardikanto dan Soebianto, 2015:122) mengemukakan bahwa kegiatan pemberdayaan pada setiap individu dalam suatu organisasi merupakan suatu siklus kegiatan yang terdiri dari:

Gambar 1.

Siklus Pemberdayaan Masyarakat Menurut Wilson

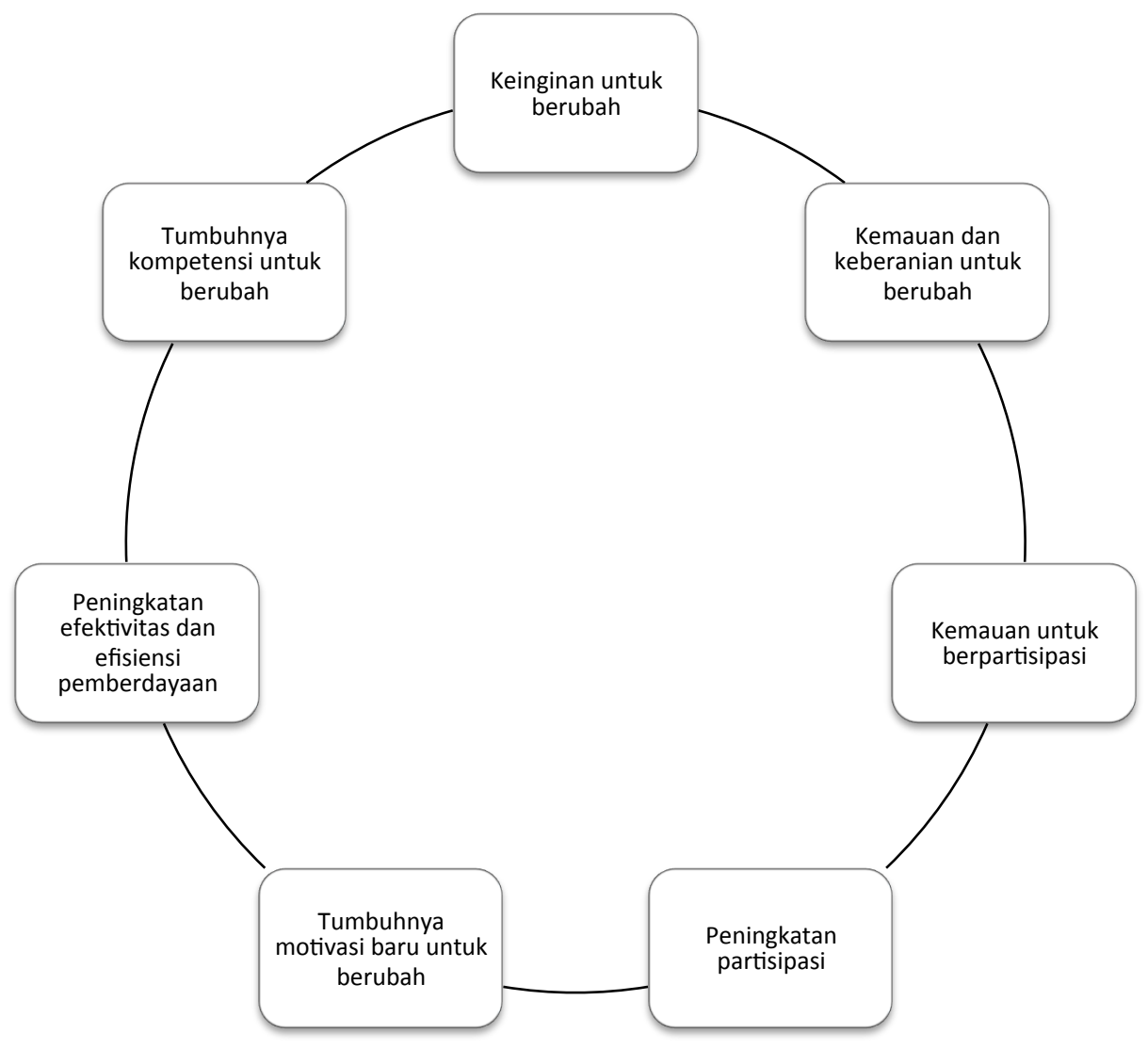

Sumber: Wilson dalam Mardikanto dan Soebianto (2015) 
a) Menumbuhkan kenginan pada diri seseorang untuk berubah dan memperbaiki, yang merupakan titik awal perlunya pemberdayaan. Tanpa adanya keinginan untuk berubah dan memperbaiki, maka semua upaya pemberdayaan masyarakat yang dilakukan tidak akan memperoleh perhatian, simpati atau partisipasi masyarakat.

b) Menumbuhkan kemauan dan keberanian untuk melepaskan diri dari kesenangan/kenikmatan dan atau hambatan-hambatan yang dirasakan, untuk kemudian mengambil keputusan mengikuti pemberdayaan demi terwujudnya perubahan dan perbaikan yang diharapkan.

c) Mengembangkan kemauan untuk mengikuti atau mengambil bagian dalam kegiatan pemberdayaan yang memberikan manfaat atau perbaikan keadaan

d) Peningkatan peran atau partisipasi dalam kegiatan pemberdayaan yang telah dirasakan manfaat/perbaikannya.

e) Peningkatan peran dan kesetiaan pada kegiatan pemberdayaan, yang ditunjukkan berkembangnya motivasi-motivasi untuk melakukan perubahan.

f) Peningkatan efektivitas dan efisiensi kegiatan pemberdayaan.

g) Peningkatan kompetensi untuk melakukan perubahan melalui kegiatan pemberdayaan baru

Menurut Mardikanto dan Soebianto (2015:167), kegiatan pemberdayaan masyarakat adalah suatu kegiatan yang memiliki tujuan yang jelas dan harus dicapai, oleh sebab itu setiap pelaksanaan pemberdayaan masyarakat perlu dilandasi dengan strategi kerja tertentu demi keberhasilannya untuk mencapai tujuan yang diinginkan. Dalam pengertian sehari-hari, strategi sering diartikan sebagai langkah-langkah atau tindakan tertentu yang dilaksanakan demi tercapainya suatu tujua atau penerima manfaat yang dikehendaki, oleh karena itu pengertian strategi sering rancu dengan metoda, teknik atau taktik.

Dalam telaahannya (Suharto,1997) terhadap starategi pemberdayaan masyarakat, ia mengemukakan adanya 5 aspek penting yang dapat dilakukan dalam melakukan pemberdayaan masyarakat, khususnya melalui pelatihan dan advokasi terhadap masyarakat miskin, yaitu:

a) Motivasi

Dalam hubungan ini, setiap keluarga harus dapat memahami nilai kebersamaan, interaksi sosial dan kekuasaan melalui pemahaman akan haknya sebagai warga negara dan anggota masyarakat. Karena itu, setiap rumah tangga perlu didorong untuk membentuk kelompok yang merupakan mekanisme kelembagaan penting untuk mengorgansir dan melaksanakan kegiatan pengembangan masyarakat di desa atau kelurahannya. Kelompok ini kemudian dimotivasi untuk terlibat dalam kegiatan peningkatan pendapatan dengan menggunakan sumber-sumber dan kemampuan-kemampuan mereka sendiri.

b) Peningkatan kesadaran dan pelatihan kemampuan

Peningkatan kesadaran masyarakat dapat dicapai melalui pendidikan dasar, perbaikan kesehatan, imunisasi dan sanitasi. Sedangkan keterampilanketerampilan vokasional bisa dikembangkan melalui cara-cara partisipatif. Pengetahuan lokal yang biasanya diperoleh melalui pengalaman dapat dikombinasikan dengan pengetahuan dari luar. Pelatihan semacam ini dapat membantu masyarakat miskin untuk menciptakan mata pencaharian sendiri atau 
membantu meningkatkan keahlian mereka untuk mencari pekerjaan di luar wilayahnya

c) Manajemen diri

Setiap kelompok masyarakat harus mampu memilih pemimpin mereka sendiri dan mengatur kegiatan mereka sendiri, seperti melaksanakan pertemuanpertemuan, melakukan pencatatan dan pelaporan, mengoperasikan tabungan dan kredit, resolusi konflik dan manajemen kepemilikan masyarakat. Pada tahap awal, pendamping dari luar dapat membantu mereka dalam mengembangkan sebuah system. Kelompok kemudian dapat diberi wewenang penuh untuk melaksanakan dan mengatur sistem tersebut

d) Mobilisasi sumberdaya

Untuk mobilisasi sumber daya masyarakat, diperlukan pengembangan metode untuk menghimpun sumber-sumber individual melalui tabungan regular dan sumbangan sukarela dengan tujuan mencipatakan modal sosial. Ide ini didasari pandangan bahwa setiap orang memiliki sumberdaya sendiri yang jika dihimpun, dapat meningkatkan kehidupan sosial ekonomi secara substansial. Pengembangan sistem penghimpunan, pengalokasian dan penggunaan sumber perlu dilakukan secara cermat sehingga semua anggota memiliki kesempatan yang sama. Hal ini dapat menjamin kepemilikan dan pengelolaan secara berkelanjutan.

e) Pembangunan dan pengembangan jejaring

Pengorganisasian kelompok-kelompok swadaya masyarakat perlu disertai dengan peningkatan kemampuan para anggotanya membangun dan mempertahankan jaringan dengan berbagai sistem sosial di sekitarnya. Jaringan ini sangat penting dalam menyediakan dan mengembangkan berbagai akses terhadap sumber dan kesempatan bagi peningkatan keberdayaan masyarakat miskin.

Edi Suharto (1998:220) menjelaskan pemberdayaan dapat dilakukan melalui tiga pendekatan yaitu:

1. Pendekatan mikro.

Pemberdayaan dilakukan terhadap individu melalui bimbingan, konseling, crisis intervention. Tujuan utamanya adalah membimbing atau melatih individu dalam menjalankan tugas-tugas kesehariannya. Model ini sering disebut sebagai pendekatan yang berpusat pada tugas (task centered approach)

2. Pendetakatan mezzo.

Pemberdayaan dilakukan terhadap kelompok masyarakat, pemberdayaan dilakukan dengan menggunakan pendekatan kelompok sebagai media intervensi. Pendidikan, pelatihan, dinamika kelompok biasanya digunakan sebagai strategi dalam meningkatkan kesadaran, pengetahuan, keterampilan serta sikap-sikap kelompok agar memiliki kemampuan memecahkan permasalahan yang dihadapi.

3. Pendekatan makro.

Pendekatan ini sering disebut dengan strategi sistem pasar (large-system strategy), karena sasaran perubahan diarahkan pada sistem lingkungan yang luas. Perumusan kebijakan, perencanaan sosial, kampanye, aksi sosial, pengorganisasian dan pengembangan masyarakat adalah beberapa strategi dalam pendekatan ini 
Pemberdayaan dapat diartikan sebagai tujuan dan proses. Sebagai tujuan, pemberdayaan adalah suatu keadaan yang ingin dicapai, yakni masyarakat yang memiliki kekuatan atau kekuasaan dan keberdayaan yang mengarah pada kemandirian sesuai dengan tipe-tipe kekuasaan yang disebutkan sebelumnya.

Menurut Suharto (1997:218-219) Pemberdayaan sebagai proses memiliki lima dimensi yaitu:

1. Pemungkinan adalah menciptakan suasana atau iklim yang memungkinkan potensi masyarakat berkembang secara optimal. Pemberdayaan harus mampu membebaskan masyarakat dari sekat-sekat struktural dan kultural yang menghambat.

2. Penguatan adalah memperkuat pengetahuan dan kemampuan yang dimiliki masyarakat dalam memecahkan masalah dan memenuhi kebutuhankebutuhannya. Pemberdayaan harus mampu menumbuhkembangkan segenap kemampuan dan kepercayaan diri masyarakat yang menunjang kemandirian.

3. Pelindungan yaitu melindungi masyarakat terutama kelompok-kelompok lemah agar tidak tertindas oleh kelompok-kelompok kuat dan dominan, menghindari persaingan yang tidak seimbang, mencegah terjadinya eksploitasi kelompok kuat terhadap yang lemah. Pemberdayaan harus diarahkan pada penghapusan segala jenis diskriminasi dan dominasi yang tidak menguntungkan masyarakat kecil. Pemberdayaan harus melindungi kelompok lemah, minoritas dan masyarakat terasing.

4. Penyokongan yaitu memberikan bimbingan dan dukungan kepada masyarakat lemah agar mampu menjalankan peran dan fungsi kehidupannya. Pemberdayaan harus mampu menyokong masyarakat agar tidak terjatuh ke dalam keadaan dan posisi yang semakin lemah dan terpinggirkan.

5. Pemeliharaan yaitu memelihara kondisi kondusif agar tetap terjadi keseimbangan distribusi kekuasaan antara berbagai kelompok masyarakat. Pemberdayaan harus mampu menjamin keseimbangan dan keselarasan yang memungkinkan setiap orang memperoleh kesempatan usaha.

Hasil Pemberdayaan Masyarakat Menurut Edi Suharto, pemberdayaan merujuk pada kemampuan orang, khususnya kelompok renta dan lemah sehingga mereka mempunyai kekuatan dan kemmapuan dalam:

a. Memenuhi kebutuhan dasarnya sehingga mereka memiliki kebebasan (freedom), dalam arti bebas dari kebodohan, bebas dari kesakitan.

b. Menjangkau sumber-sumber produktif yang memungkinkan mereka dapat meningkatkan pendapatannya dan memperoleh barang-barang dan jasa-jasa yang mereka perlukan.

c. Berpartisipasi dalam proses pembangunan dan keputusan- keputusan yang mempengaruhi mereka.

Dari pemaparan tersebut dapat disimpulkan bahwa hasil pemberdayaan dapat dilihat dari tingkat pemenuhan kebutuhan, peningkatan pendapatan, dan partisipasi.

Berdasarkan uraian diatas, pada penelitian ini peneliti akan menggunakan pendekatan pemberdayaan yang dikemukakan oleh Suharto (1997), karena peneliti berasumsi bahwa pendekatan pemberdayaan yang dikemukakan oleh Suharto ada keterkaitan satu sama lainnya dengan permasalahan yang peneliti temukan tentang 
Proses Pemberdayaan Masyarakat dalam Program Keterampilan melalui Gerakan Pemberdayaan dan Kesejahteraan Keluarga (PKK). Selain itu pendekatan pemberdayaan yang dikemukakan oleh Suharto dalam penelitian ini dapat dilihat dari aspek $5 \mathrm{P}$ yaitu pemungkinan, penguatan, perlindungan, penyokongan, pemeliharaan.

\section{Metode Penelitian}

Metode penelitian yang digunakan dalam penelitian ini adalah deskriptif kualitatif, karena penelitian ini bertujuan untuk memperoleh gambaran yang diteliti. Dalam hal penelitian ini penulis mengungkapkan penelitian kualitatif dengan penelitian yang dilakukan dalam setting tertentu yang ada dalam kehidupan sebenarnya dengan maksud menginvestigasi dan memahami fenomena apa yang terjadi yaitu kualitas pelayanan kesehatan yang ada di Kecamatan Subang Kabupaten Subang. Dengan menggunakan pendekatan kualitatif, yang berbasis pada informasi/kenyataan yang terjadi di lapangan. Adapun prosedur-prosedur pada pendekatan kualitatif yaitu : pengambilan informan secara sengaja, pengumpulan data terbuka, analisis teks atau gambar, serta interpretasi pribadi atas temuan-temuan. Langkah-langkah untuk pengumpulan data meliputi usaha membatasi penelitian, mengumpulkan informasi melalui observasi dan wawancara, baik yang terstruktur maupun tidak, dokumentasi, materi-materi visual, serta usaha merancang protokol untuk merekam / mencatat informasi. Denzin dan Lincoln (Moleong, 2005:4) menyatakan bahwa metodologi kualitatif penelitian yang menggunakan latar belakang alamiah, dengan maksud menafsirkan fenomena yang terjadi dan dilakukan dengan jalan melibatkan berbagai metode yang ada. Dari uraian di atas maka tujuan utama menggunakan penelitian kualitatif ialah mengembangkan pengertian, konsep-konsep yang pada akhirnya memperoleh gambaran yang kemudian diarahkan pada deskripsi kualitas pelayanan kesehatan di Kecamatan Subang Kabupaten Subang. Sumber data yang digunakan dalam penelitian ini adalah :

a. Data Primer, yaitu data yang diperoleh dari sumbernya dengan melakukan studi lapangan yaitu dengan wawancara langsung dengan nara sumber yaitu informan.

b. Data Sekunder, yaitu data yang diperoleh daru studi kepustakaan dan dokumentasi yaitu dengan cara mengumpulkan data dari literatur, buku, dokumen, makalah dan pemberitaan yang ada hubungannya dengan masalah yang penulis kemukakan serta mengumpulkan data-data dari Kecamatan Subang Kabupaten Subang.

Penentuan informan dalam penelitian ini melalui penentuan informan yang mula-mula jumlahnya kecil, kemudian membesar. Penentuan informan ini digunakan mengingat sumber data belum lengkap jika mengambil sumber data hanya berjumlah satu atau dua orang informan, karena penulis melakukan penelitian tentang Proses Pemberdayaan Masyarakat melalui PKK, maka informan mula-mula adalah satu orang, kemudian terus berkembang pada pihak-pihak lain sehingga informan terus berkembang sampai ditemukannya informasi yang 
menyeluruh atas permasalahan yang diteliti. Yang menjadi informan dalam penelitian ini adalah :

a. Camat Kecamatan Subang Kabupaten Subang, informan ini dipilih karena dapat memberikan informasi mengenai Kebijakan pembinaan PKK di Kecamatan Subang.

b. Ketua dan Pengurus TP PKK Kecamatan Subang Kabupaten Subang, informan ini dipilih karena dapat memberikan informasi mengenai kualitas berbagai kegiatan pemberdayaan PKK di Kecamatan Subang.

c. Beberapa Keluarga di wilayah kelurahan se-wilayah Kecamatan Subang Kabupaten Subang, informan ini dipilih karena dapat memberikan informasi realisasi mengenai kegiatan-kegiatan pemberdayaan PKK yang telah diberikan, adapun informan tediri dari keluarga yang berada di kelurahan se-Kecamatan Subang dan Desa Belendung Kecamatan Subang Kabupaten Subang.

Pendekaatan ini bersifat kualitatif sehingga informasi yang paling penting adalah peneliti itu sendiri, karena peneliti yang bertugas menyusun atau merekomendasikan alat (instrumen), jadi harus memahami segala hal yang berhubungan dengan penelitian yang dilakukan. Instrumen pengambilan data menentukan kualitas perolehan data yang dikumpulkan. Data yang berkualitas berakibat pada kualitas penelitian yang dilakukannya. Dalam tahap penelitian menggunakan instrumen berupa :

a. Pedoman wawancara terhadap obyek yang berhubungan dengan masalah yang ingin diteliti.

b. Catatan-catatan sistematis yang disusun pada saat dilakukan observasi dilapangan yang dapat membantu untuk merekam berbagai hal yang berhubungan dengan obyek yang ingin diteliti.

Teknik pengumpulan data yang dilakukan penulis adalah sebagai berikut:

1. Penelitian perpustakaan, yaitu melakukan studi kepustakaan, dengan mempelajari teori-teori yang bersumber pada buku-buku perpustakaan, artikelartikel, makalah-makalah untuk mendapatkan pengetahuan yang mempunyai relevansi serta sebagai landasan untuk menjawab permasalahan penelitian.

2. Penelitian lapangan, bertujuan untuk memperoleh data yang diharapkan dapat membantu dalam proses atau menganalisis permasalahan dengan tujuan langsung ke lapangan, dalam penelitian ini data diperoleh dengan :

a. Dokumentasi, untuk mengumpulkan data primer dan sekunder, penulis menganalisa dokumen-dokumen dalam bentuk tulisan yang berkaitan dengan tujuan penelitian.

b. Observasi, untuk memperoleh informasi serta gambaran empirik tentang datadata yang diperlukan dengan mengadakan pengamatan langsung pada obyek penelitian.

c. Wawancara, adalah percakapan langsung dengan maksud untuk memperkuat data sekunder yang diperlukan dalam penelitian. Percakapan itu dilakukan oleh dua pihak yaitu pewawancara (interviewer) yang mengajukan pertanyaan dan yang diwawancarai (informan). Tehnik wawancara yang digunakan adalah wawancara terbuka (open interview) dengan maksud agar informan tahu bahwa mereka sedang diwawancarai dan mengetahui pula maksud wawancara tersebut. Untuk itu instrumen penelitian yang digunakan adalah 
pedoman wawancara (interview guide) yang merupakan penuntun bagi peneliti dalam mengembangkan pertanyaan-pertanyaan yang bersifat terbuka sehingga memberikan kebebasan yang seluas-luasnya bagi informan untuk menyampaikan pendapatnya.

Dalam penelitian kualitatif, temuan atau data dapat dinyatakan valid apabila tidak ada perbedaan antara yang dilaporkan peneliti dengan apa yang sesungguhnya terjadi pada objek yang diteliti. Tetapi perlu diketahui bahwa kebenaran realitas data menurut penelitian kualitatif tidak bersifat tunggal, tetapi jamak dan tergantung pada konstruksi manusia, dibentuk dalam diri seorang sebagai hasil proses mental tiap individu dengan berbagai latar belakangnya. Langkah yang umum digunakan dalam validitas data yaitu triangulasi. Menurut Wiliam Wiersma (Sugiyono, 2010:273) menyatakan bahwa : Triangulasi dalam pengujian kredibilitas ini diartikan sebagai pengecekan data dari berbagai sumber dengan berbagai cara, dan berbagi waktu. Moleong (2005:330) mengemukakan bahwa triangulasi adalah teknik pemeriksaan data yang memanfaatkan sesuatu yang lain. Diluar data itu untuk keperluan pengecekan atau sebagai pembanding terhadap data itu. Dengan kata lain dengan triangulasi, peneliti dapat me recheck temuannya dengan jalan membandingkannya dengan berbagai sumber, metode atau teori. Untuk itu maka peneliti dapat melakukannya dengan jalan :

1. Mengajukan berbagai macam variasi pertanyaan.

2. Mengeceknya dengan berbagai sumber data.

3. Memanfaatkan berbagai metode agar pengecekan kepercayaan data dapat dilakukan.

Adapun triangulasi yang penulis gunakan adalah dengan cara mengajukan berbagai macam variasi pertanyaan serta mengeceknya dengan berbagai sumber data. Triangulasi itu sendiri pada hakikatnya merupakan pendekatan multimetode yang dilakukan peneliti pada saat mengumpulkan dan menganalisis data. Ide dasarnya adalah bahwa fenomena yang diteliti dapat dipahami dengan baik sehingga diperoleh kebenaran tingkat tinggi jika didekati dari berbagai sudut pandang. Memotret fenomena tunggal dari sudut pandang yang berbeda-beda akan memungkinkan diperoleh tingkat kebenaran yang handal. Karena itu, triangulasi ialah usaha mengecek kebenaran data atau informasi yang diperoleh peneliti dari berbagai sudut pandang yang berbeda dengan cara mengurangi sebanyak mungkin bias yang terjadi pada saat pengumpulan dan analisis data. Data yang telah dikumpulkan diterjemahkan dan diolah sedemikian rupa sampai berhasil menyimpulkan kebenaran-kebenaran yang nantinya dapat dipakai untuk menjawab persoalan-persoalan yang disajikan dalam penelitian. Analisis data merupakan bagian yang penting dalam metode ilmiah, dengan analisis tersebut dapat diberi arti dan makna yang berguna dalam memecahkan masalah penelitian itu sendiri. Analisis data kualitatif menurut Seiddel (dalam Moleong, 2005:248) prosesnya berjalan sebagai berikut : 1) Mencatat yang menghasilkan catatan lapangan, dengan hal itu diberi kode agar sumber datanya tetap dapat ditelusuri, 2) Mengumpulkan, memilah-milah, mengklasifikasikan, mensintesiskan, membuat ikhtisar dan membuat indeksnya, 3) Berpikir dengan jalan membuat agar kategori data itu mempunyai makna, mencari dan menemukan pola dan hubungan-hubungan dan membuat temuan-temuan umum. Analisis data ini didasarkan pada suatu upaya 
dan pertimbangan bahwa setelah data dikumpulkan dari lokasi penelitian, selanjutnya dapat dianalisis untuk menggambarkan keadaan yang sebenarnya sehingga dapat berguna memecahkan masalah yang dihadapi

\section{Hasil dan Diskusi}

\section{Gambaran Umum Gerakan Pemberdayaan Kesejahteraan Keluarga}

a. Gerakan Pemberdayaan Kesejahteraan Keluarga Kabupaten Subang

Gerakan PKK adalah gerakan nasional dalam pembangunan masyarakat yang tumbuh dari bawah, pengelolaannya dari, oleh, dan untuk masyarakat menuju terwujudnya keluarga yang beriman dan bertaqwa kepada TUHAN YME, berakhlak mulia dan berbudi luhur, sehat sejahtera, lahir dan batin

Dasar Hukum TP.PKK Adalah Peraturan Presiden Republik Indonesia Nomor 99 Tahun 2017 Tentang Gerakan Pemberdayaan dan Kesejahteraan Keluarga, Peraturan Menteri Dalam Negeri Republik Indonesia Nomor. 1 tahun 2013 Tentang Pemberdayaan Masyarakat Melalui Gerakan Pemberdayaan Dan Kesejahteraan Keluarga

Organisasi TP.PKK adalah Organisasi yang berjenjang dari Tingkat Pusat sampai Tingkat RT, dan memiliki Kelompok Dasawisma yang menjadi ujung tombak setiap kegiatan di Desa. Dengan memiliki Strategi yaitu melibatkan Seluruh TP.KK dan semua kader PKK secara aktif, sistematis dan berkesinambungan dalam pelaksanaan 10 program pokok PKK. Hubungan Kerja TP.PKK Setiap Jenjang adalah bersifat konsultatif, koordinatif dan hirarkis.

\section{b. Tujuan}

Gerakan PKK bertujuan memberdayakan keluarga untuk meningkatkan kesejahteraan menuju terwujudnya keluarga yang beriman dan bertaqwa kepada TUHAN YME, berakhlak mulia dan berbudi luhur, sehat sejahtera, lahir dan bathin c. Sasaran

Sasaran Kerja TP.PKK adalah keluarga baik di pedesaan maupun perkotaan yang perlu ditingkatkan dan dikembangkan kemampuan dan kepribadiannya dalam bidang :

1. Mental Spiritual : Sikap Dan Perilaku Sebagai Insan Hamba Tuhan, Anggota Masyarakat Dan Warga Negara Yang Dinamis Serta Bermanfaat Berdasarkan Pancasila dan UUD 1945

2. Fisik Material : Pangan, Sandang, Papan, Kesehatan, Kesempatan Kerja Yang Layak Serta Lingkungan Hidup Yang Sehat Dan Lestari Melalui Peningkatan Pendidikan, Pengetahuan Dan Keterampilan

d. Visi dan Misi PKK

PKK memiliki Visi yaitu terwujudnya keluarga yang beriman dan bertaqwa kepada TUHAN YME, berakhlak mulia dan berbudi luhur, sehat sejahtera, lahir dan bathin.

Misi PKK yaitu 
1. Meningkatkan Pembentukan Karakter Keluarga Melalui Penghayatan, Pengamalan Pancasila, Kegotongroyongan Serta Kesetaraan Dan Keadilan Gender

2. Meningkatkan Pendidikan Dan Ekonomi Keluarga Melalui Berbagai Upaya Keterampilan Dan Pengembangan Koperasi

3. Meningkatkan Ketahanan Keluarga Melalui Pemenuhan Pangan, Sandang Dan Perumahan Sehat Dan Layak Huni

4. Meningkatkan Derajat Kesehatan Keluarga Serta Perencanaan Sehat

5. Meningkatkan Pengelolaan Gerakan PKK Meliputi Kegiatan Pengorganisasian Dan Peningkatan SDM

e. Program Pokok PKK

Terdapat 10 Program Pokok PKK yang dimiliki oleh TP.PKK yaitu

1. Penghayatan Dan Pengamalan Pancasila

2. Gotong Royong

3. Pangan

4. Sandang

5. Perumahan Dan Tata Laksana Rumah Tangga

6. Pendidikan Dan Keterampilan

7. Kesehatan

8. Pengembangan Kehidupan Berkoperasi

9. Kelestarian Lingkungan Hidup

10. Perencanaan Sehat

f. Tugas dan Fungsi TP.PKK

1. Tugas TP.PKK

1. Merencanakan, Melaksanakan Dan Membina Pelaksanaan Program Kerja TP.PKK Sesuai Dengan Keadaan Dan Kebutuhan Masyrakat

2. Menghimpun, Menggerakan Dan Membina Potensi Masyarakat, Khususnya Keluarga Untuk Terlaksana Program TP.PKK

3. Memberikan Bimbingan, Motivasi Dan Memfasilitasi TP.PKK Di Bawahnya

4. Menyampaikan Laporan Pelaksanan Tugas Kepada Ketua Pembina TP.PKK Setempat Dan Kepada Ketua TP.PKK Setingkat Diatasnya

5. Melakukan Supervisi, Monitoring, Evaluasi Dan Pelaporan Terhadap Pelaksanaan Program TP.PKK

2. Fungsi TP.PKK

1. Penyuluh, Motivator Dan Penggerak Masyarakat Agar Mau Dan Mampu Melaksanakan Program TP.PKK

2. Fasilitator, Perencanaan, Pelaksanaan, Pengendali, Pembina Dan Pembimbing TP.PKK

g. Hubungan Kerja

1. Hubungan kerja antar TP.PKK di semua jenjang, bersifat konsultatif dan koordinatif dengan tetap memperhatikan hubungan hirarkis

2.Hubungan kerja antara TP.PKK dengan Pemerintah, Lembaga Kemasyarakatan yang memiliki kepedulian terhadap Pemberdayaan dan Kesejahteraan Keluarga bersifat kemitraan

3. Hubungan kerja antara TP.PKK dengan Pembina, bersifat konsultatif 
4. Hubungan kerja antara TP.PKK Desa / Kelurahan dengan LPMD atau sebutan lain, bersifat konsultatif, koordinatif dan kerjasama yang saling menguntungkan

5. Hubungan kerja antara TP.PKK dengan dunia usaha, donor dalam dan luar negeri bersifat kemitraan yang saling menguntungkan.

\section{Proses Pemberdayaan Masyarakat melalui Gerakan Pemberdayaan dan Kesejahteraan Keluarga Kabupaten Subang}

Berdasarkan hasil penelitian yang telah dilakukan di Kantor TP.PKK Kabupaten Subang Jalan Dewi Sartika No. 2 Kecamatan Subang Kabupaten Subang dan Lingkungan Kecamatan Subang. Proses Pemberdayaan Masyarakat melalui Gerakan Pemberdayaan dan Kesejahteraan Keluarga dapat dilihat dari strategi pemberdayaan menurut Suharto (1997), sebagai berikut :

\section{Pemungkinan}

Pemungkinan adalah menciptakan suasana atau iklim yang memungkinkan potensi masyarakat berkembang secara optimal. Pemberdayaan harus mampu membebaskan masyarakat dari sekat-sekat struktural dan kultural yang menghambat.

Masyarakat harus dapat memahami nilai kebersamaan, interaksi sosial dan kekuasaan. Karena itu, setiap masyarakat perlu didorong untuk melaksanakan kegiatan pengembangan masyarakat, kemudian dimotivasi untuk terlibat dalam kegiatan peningkatan pendapat dengan kemampuan mereka sendiri seperti mengembangkan potensi yang ada di alam dan potensi dari dirinya sendiri. Ketua TP.PKK Kab. Subang mengatakan Sebagai berikut : "Kabupaten Subang mempunyai 30 Kecamatan dengan 3 wilayah / Zona yaitu Daerah Pantai, Daerah Dataran Rendah dan Daerah Pegunungan. Dengan demikian potensi yang dimiliki setiap kecamatan pasti berbeda, dari mata pencaharian dan juga hasil potensi Sumber Daya Alamnya, seperti daerah pantai potensinya seperti perikanan laut dan tambak, daerah dataran potensinya seperti pertanian, dan kehutanan, daerah pegunungan potensinya seperti perkebunan dan persawahan. Sehingga setiap wilayah memiliki penanganan yang berbeda-beda disebabkan oleh watak / karakter masyarakatnya berbeda-beda. Memanfaatkan potensi yang ada di setiap daerah untuk dijadikan produk unggulan sehingga dapat meningkatkan ekonomi masyarakat, bukan hanya industri Rumah Tangga yang dapat dikembangkan tetapi Sumber Daya Alam juga bisa dikembangkan menjadi daerah wisata". Sekretaris TP.PKK Kab. Subang mengatakan: "Banyak kendala yang dihadapi dalam pengembangan potensi masyarakat seperti :

1. Sumber Daya Manusia yang kurang profesional dalam mengelola potensi yang ada.

2. Kurang harmonis dan koordinasi antara perangkat desa, lembaga-lembaga yang ada di desa dan OPD terkait di dalam mengelola potensi alam yang ada

3. Kurang aktifnya pengurus di tingkat kecamatan dan desa

4. Kurangnya pemahaman tentang pengemasan dan pemasaran produk lokal masyarakat

Sehingga PKK mengembangkan potensi yang ada di masyarakat melalui : 
1. Memanfaatkan potensi yang ada di daerah masing-masing untuk dijadikan produk unggulan sehingga dapat meningkatkan ekonomi masyarakat

2. Meningkatkan pengetahuan dan keterampilan masyarakat melalui Sosialisasi, Penyuluhan, Pelatihan-pelatihan serta Orientasi yang bekerjasama dengan OPD terkait sehungga dapat meningkatkan pengetahuan masyarakat

3. Didalam pengolahan Industri Rumah Tangga perlu adanya peningkatan Kualitas, Rasa, Kemasaan, Label dan pencantuman Tanggal Kadaluarsa dan Pemasaran sehingga PKK bekerjasama dengan OPD terkait mengadakan pelatihan wirausaha kepada pengurus dan sekaligus membantu pemasaran dan pemasaran hasil produk-produk unggulan sehingga dapat meningkatkan ekonomi masyarakat "

Kader TP.PKK memberikan pendapatnya terkait permasalahan ini sebagai berikut : Masih kurangnya sosialisasi dan pelatihan, sehingga masyarakat belum bisa mengembangkan potensi yang ada dan memanfaatkan sumber daya alam yang ada. Selain itu banyak kendala yang harus dihadapi seperti sumber daya manusia yang kurang memadai (umur yang tua, gagap teknologi, pendidikan yang rendah, dan lainnya), jarak tempuh warga dari tempat tinggal ke lokasi pelatihan yang jauh, kurang aktifnya pengurus PKK ditingkat desa membuat kita kadang-kadang tidak mengenal mereka ditambah kurangnya dukungan dari pejabat-pejabat setempat dan tokoh masyarakat sehingga membuat masyarakat tidak bersemangat mengikuti pelatihan-pelatihan tersebut". Dalam pelaksanaan Pemungkinan masih mengalami berbagai hambatan. Pendapat yang sama juga dikemukakan oleh masyarakat sebagai berikut: "Seharusnya rutin diadakan pelatihan-pelatihan dan penyuluhan, karena warga butuh kegiatan seperti itu untuk menambah pengetahuan,keterampilan dan penambahan pendapatan. Ini mah jarang diadakan pelatihan langsung ke warga, Apalagi jika bahan-bahan keterampilanya mudah kita dapat dan tidak memerlukan modal besar. Jadi warga tidak tau bagaimana memanfaatkan limbah-limbah yang ada, karena menghasilkan suatu keterampilan itu dibutuhkan pengetahuan dan ketekunan. Terus lokasi kegiatannya harusnya dekat dengan lingkungan masyarakat supaya kita tidak mengeluarkan biaya transport, karena kita tidak semua bisa menggunakan motor. Kalau bisa ada bantuan modal awal dari pemerintah. Seharusnya ada dukungan pula dari tokoh masyarakat untuk menggerakkan kegiatan PKK ini". Pemungkinan bisa diartikan sebagai salah satu yang dibutuhkan dalam proses pemberdayaan masyarakat. Untuk mendapatkan hasil yang optimal diperlukan pemungkinan yang baik, karena pemungkinan bisa mempengaruhi hasil dari proses pemberdayaan masyarakat (Hikmawan \& Hidayat, 2016). Karena dengan pengembangan potensi yang menyeluruh dengan memperbanyak pelatihan-pelatihan keterampilan, sosialisasisosialisasi sehingga masyarakat bisa merubah pola pikir dan cara pandang mereka tentang manfaat potensi yang ada di masyarakat. Tetapi banyak kendala yang harus dihadapi seperti SDM yang kurang memadai (faktor usia, faktor pendidikan,dan faktor kebiasaan), anggaran yang terbatas, kurang dukungan dari OPD-OPD terkait dan pejabat setempat.

Berdasarkan hasil beberapa wawancara diatas dapat ditarik kesimpulan, bahwa pemungkinan proses pemberdayaan masyarakat melalui gerakan pemberdayaan dan kesejahteraan keluarga dinilai belum berjalan dengan optimal. Hal tersebut dinilai demikian berdasarkan sudut pandang peneliti dan hasil 
wawancara, dimana banyak faktor yang mempengaruhi sehingga pemungkinan dalam proses pemberdayaan masyarakat tidak bisa berjalan sesuai harapan.

\section{Penguatan}

Penguatan adalah memperkuat pengetahuan dan kemampuan yang dimiliki masyarakat dalam memecahkan masalah dan memenuhi kebutuhan-kebutuhannya. Pemberdayaan harus mampu menumbuh kembangkan segenap kemampuan dan kepercayaan diri masyarakat yang menunjang kemandirian. Peningkatan kesadaran masyarakat dapat dicapai melalui pendidikan dasar, perbaikan kesehatan, perbaikan lingkungan dan sanitasi. Sedangkan keterampilan-keterampilan bisa dikembangkan melalui cara-cara partsipasi. Pengetahuan lokal yang biasanya diperoleh melalui pengalaman dapat dikombinasikan dengan pengetahuan dari luar. Pelatihan semacam ini dapat membantu masyarakat untuk menciptakan mata pencaharian sendiri atau membantu meningkatkan keahlian mereka untuk mencari pekerjaan di luar. Adapun hasil wawancara dengan Sekretaris TP.PKK Kab. Subang sebagai berikut: "Untuk penguatan pengurus dilakukan dengan cara menambah pengetahuan dan keterampilan antara lain :

1. Diadakan pelatihan-pelatihan bagi pengurus, penambahan pengetahuan dari hasil rapat-rapat supaya bisa bertukar informasi diantara pengurus, sehingga diharapkan bisa menambah pengetahuan para pengurus agar dapat memsosialisasikan lagi kepada masyarakat

2. Diadakan bimbingan teknis kepada Pengurus PKK Kecamatan,, Kader, serta Tokoh masyarakat.

3. Melaksanakan pembinaan-pembinaan langsung ke lokasi desa terpilih untuk persiapan perlombaan tingkat provinsi seperti Lomba Desa, Lomba P2WKSS, Lomba 10 Program PKK dan BBGR, Lomba Kesatuan Gerak PKK KB KES, Lomba Pelaksana Toga Terbaik, dan lain-lain

Tetapi dalam menjalankan program penguatan tersebut banyak kendala antara lain :

1. Sumber Daya Manusia yang kurang seperti umur kader yang tidak muda lagi, pendidikan kader yang rendah sehingga mereka banyak yang gagap teknologi dan tidak bisa memanfaatkan teknologi masih cenderung Tradisional

2. Kebiasaan gemar membaca masyarakat masih jauh dari harapanan, pemanfaatan perpustakaan desa atau sudut-sudut baca kurang dimanfaatkan oleh masyarakat

Selanjutnya peneliti mewawancarai Kader yaitu sebagai berikut : “ Jarang adanya pertemuan rutin bagi kader padahal kader adalah ujung tombak gerakan PKK, bisa menyampaikan informasi secara mensosialisasikannya di berbagai tempat seperti posyandu, majelis taklim, arisan, kumpulan ibu-ibu. Dengan mensosialisasikan secara sering berbagai informasi kepada masyarakat diharapkan bisa merubah pola pikir, karakter dan bisa merubah kebiasaan masyarakat. Mengajak membaca kepada warga pun susah dilakukan karena mereka selalu mengeluh tidak ada waktu. Kebanyakan kan kader sudah berumur, sehingga mereka terkadang banyak yang gagap teknologi, seperti penggunaan handphone android, mereka terkadang suka agak kesulitan memakainya. Ditambah kami pun agak sulit membuat laporan PKK karena banyak yang kita tidak mengerti disebabkan terlalu banyak yang harus diisi. " 
Berdasarkan hasil wawancara diatas dapat dijelaskan bahwa untuk mengoptimalkan proses pemberdayaan masyarakat diperlukan pengetahuan yang terbaru dan terlengkap sehingga bisa mengajak masyarakat untuk berubah ke arah yang lebih baik, bisa merubah pola pikir masyarakat dan bisa merubah kebiasaan masyarakat Hal ini sejalan dengan pendapat masyarakat yaitu sebagai berikut : “ Para kader kadang-kadang tidak menyampaikan apa-apa kepada warga, padahal kita membutuhkan banyak informasi yang terbaru tentang segala hal. Karena pengaruh Kader dalam mensosialisasikan kepada masyarakat sangat penting. Kita suka mendapat tambahan informasi dari kader seperti tentang penyakit yang baru, penyebab terjangkitnya dan cara pencegahannya. Walaupun suka kurang lengkap juga sih infonya. Karena kalo membaca buku langsung kita suka ngantuk sedangkan untuk browsing ke internet kita tidak mengerti bagaimana cara membukanya." Dalam hasil wawancara diatas dapat ditarik kesimpulan, bahwa penguatan dalam proses pemberdayaan masyarakat melalui gerakan pemberdayaan dan kesejahteraan keluarga dinilai belum berjalan dengan optimal, hal tersebut didasarkan pada pengaruh kader yang mensosialisasikan kepada masyarakat tentang berbagai informasi seperti pentingnya pendidikan, kesehatan dan masih banyak lagi. Penerimaan informasi yang diterima masyarakat dipengaruhi oleh pengetahuan yang dimiliki, dipengaruhi bagaimana cara penyampaian kader dari cara bicara, mimik wajah dan postur tubuh kader dan cara mengajak masyarakat untuk hidup lebih baik lagi. Karena diharapkan dengan ini bisa mengubah cara pandang, pola pikir dan bisa merubah kebiasaan masyarakat Apalagi sekarang zaman millenial sehingga diharapkan para kader diharapkan bisa mengikuti teknologi, jangan terlalu gagap teknologi.

\section{Perlindungan}

Pelindungan yaitu melindungi masyarakat terutama kelompok-kelompok lemah agar tidak tertindas oleh kelompok-kelompok kuat dan dominan, menghindari persaingan yang tidak seimbang. Pemberdayaan harus diarahkan pada penghapusan segala jenis diskriminasi dan dominasi yang tidak menguntungkan masyarakat kecil. Pemberdayaan harus melindungi kelompok lemah, minoritas dan masyarakat terasing. Pendampingan dari luar dapat membantu mereka dalam mengembangkan sebuah sistem. kemudian dapat diberi wewenang penuh untuk melaksanakan dan mengatur sistem tersebut.

Adapun hasil wawancara dengan Sekretaris tentang perlindungan sebagai berikut : "Cara TP.PKK untuk melindungi masyaraka dari segala jenis diskriminasi dan kriminalisasi dantara lain :

1. a. Melalui Pokja I, masyarakat dibina dan diberi penyuluhan tentang Hukum, Hak-hak Anak dan Perempuan, Hak Azasi Manusia, Trafiking, KDRT. Bentuk penyuluhan bisa melalui kelompok Simulasi dan Kelompok-kelompok pengajian. Bisa juga kerjasama dengan Posyandu.

b. Melalui pokja II, masyarakat dibina tentang pendidikan dan keterampilan. Bentuk penyuluhan bisa melalui kelompok Simulasi BKB, memasyarakatkan perpustakaan dan pelatihan keterampilan agar bisa menambah penghasilan masyarakat. 
c. Melalui Pokja III, masyarakat dibina tentang manfaat Pangan, pengembangan sandang, pemanfaatan perumahan dan tata laksana rumahtangga.

d. Melalui Pokja IV, masyarakat dibina tentang penyuluhan Kesehatan, sosialisasi Kelestarian Lingkungan Hidup, meningkatkan perencanaan sehat masyarakat.

2. Dibentuk Forum Komunikasi KDRT disetiap Desa/Kelurahan dengan tujuan cepat menangani kasus yang dihadapi masyarakat dan menjadi tempat konseling bagi masyarakat yang memerlukan konsultasi

3. Dibentuk kelompok Pola Asuh Anak dan Remaja di setiap Posyandu.

4. Mensosialisaikan tentang ketahanan keluarga sebagai benteng utama untuk melindungi keluarga dari permasalahan dengan melaksanakan 8 fungsi keluarga. 8 fungsi keluarga yaitu : fungsi Agama, fungsi sosial budaya, fungsi cinta dan kasih sayang, fungsi perlindungan, fungsi Reproduksi, fungsi Sosialisasi dan Pendidikan, fungsi Ekonomi, fungsi Lingkungan.

Tetapi banyak kendala yang dihadapi gerakan PKK seperti kurangnya perhatian dari kepala desa dan aparat desa akan peran PKK dalam melindungi Masyarakat dan pembangunan Manusia. Belum semua OPD terkait mendukung sepenuhnya kegiatan TP.PKK dalam perlindungan masyarakat. Karena banyak sekali kasuskasus yang terjadi di masyarakat, antara lain : Trafiking, kenakalan remaja, kasus asusila anak-anak, kasus HIV-AIDS, KDRT. Pelecehan sexsual, dan sebagainya." Selanjutnya peneliti mewawancarai Kader yaitu sebagai berikut: "Masih banyak masyarakat yang belum mengetahui tentang segala kriminalitas yang terjadi dimasyarakat. Terkadang malah mereka mengganggap hal itu adalah hal yang biasa bukan kriminalitas sehingga terkadang mereka tidak peduli atau cuek padahal seharusnya dilaporkan kepada pihak terkait. apalagi sekarang banyak kasus-kasus yang terjadi di masyarakat, yang ternyata cukup meresahkan masyarakat. Masih kurangnya Sosialisasi dan penyuluhan, serta belum ada dukungan yang serius dari OPD terkait sehingga PKK susah untuk berkembang, padahal setiap perlombaan baik tingkat kabupaten maupun tingkat provinsi. Ditambah dengan keterbatasan anggaran yang ada membuat pengurus dan kader sulit untuk maju". Berdasarkan hasil wawancara diatas dapat dijelaskan bahwa untuk mengoptimalkan proses pemberdayaan masyarakat diperlukan pengetahuan tentang segala kriminalitas dan diskriminasi yang di temui oleh masyarakat, belum adanya tempat untuk konsultasi masyarakat, perlu adanya dukungan dari OPD-OPD terkait. Hal ini sejalan dengan pendapat masyarakat yaitu sebagai berikut : "Ketidaktahuan tentang macammacam tindakan kriminalitas yang terjadi, membuat kita bingung apa yang harus dilakukan, dan kita harus melapor kemana. Karena banyak korban yang malu untuk bercerita apa yang telah mereka alami kepada orang lain karena itu aib bagi mereka. Jenis-jenis kriminal pun kita kadang tidak tahu, karena kita menyadari bahwa kita jarang membaca buku, membaca koran serta menonton tv. Ditambah sekarang banyak penyakit-penyakit yang berbahaya bermunculan. Warga tuh ingin ada penyuluhan dan pelatihan langsung supaya kita tahu apa informasi yang terbaru. " Dalam hasil wawancara diatas dapat ditarik kesimpulan, bahwa perlindungan dalam proses pemberdayaan masyarakat melalui gerakan pemberdayaan dan kesejahteraan keluarga dinilai belum berjalan dengan optimal, disebabkan oleh 
masih kurangnya sosialisasi atau penjelasan tentang segala macam kriminalitas yang mengincar kita semua dan tidak mengetahui tindakan-tindakan kriminalitas yang terjadi dimasyarakat. Pelaksanaan ketahanan keluarga belum berjalan secara optimal, belum adanya tempat untuk konsultasi masyarakat, dan kurangnya dukungan dari Pejabat Setempat

\section{Penyokongan}

Penyokongan yaitu memberikan bimbingan dan dukungan kepada masyarakat lemah agar mampu menjalankan peran dan fungsi kehidupannya. Pemberdayaan harus mampu menyokong masyarakat agar tidak terjatuh ke dalam keadaan dan posisi yang semakin lemah dan terpinggirkan. Adanya pengembangan metode untuk menghimpun sumber-sumber individual jika dihimpun, dapat meningkatkan kehidupan sosial ekonomi secara substansial. Pengembangan sistem penghimpunan, pengalokasian dan penggunaan sumber perlu dilakukan secara cermat sehingga semua anggota memiliki kesempatan yang sama. Adapun hasil wawancara dengan Sekretaris TP.PKK Kab. Subang sebagai berikut: “ Banyak yang telah di lakukan oleh TP.PKK dalam penyokong masyarakat seperti

1. Menjadi mediator kepada OPD terkait

2. Bekerjasama dengan OPD terkait memberikan konseling dan Bimbingan kepada masyarakat

3. Memberikan kegiatan berupa keterampilan sesuai dengan potensi yang ada.

4. Membantu untuk memasarkan hasil Produk-produk UP2K dan Produk hasil Keterampilan yang dibuat oleh masyarakat seperti dalam pameran-pameran "

Selanjutnya peneliti mewawancarai Kader TP.PKK yaitu sebagai berikut : “ Seharusnya adanya tempat konseling sebagai wadah tempat curhat korban segala kriminalitas yang terjadi dimasyarakat. Supaya masyarakat bisa lebih leluasa berceritanya tidak canggung dan langsung dapat penanganan dari masalah yang mereka hadapi. Adanya kelompok Pola Asuh Anak dan Remaja, sehingga masyarakat tahu bagaimana menghadapi remaja di jaman milenia ini. Selain itu Masyarakat diberikan pelatihan keterampilan pemanfaatan dari bahan-bahan bekas, membuat bank sampah, dan lain-lain. Sehingga masyarakat bisa lebih produktif dan mendapatkan tambahan penghasilan dan membantu mempromosikan hasil keterampilan masyarakat dan hasil UP2K ". Berdasarkan hasil wawancara diatas dapat dijelaskan bahwa untuk mengoptimalkan proses pemberdayaan masyarakat diperlukan pembinaan dan dibentuk wadah untuk tempat curhat korban kriminalitas, supaya korban tidak malu cerita dan langsung dapat penangannan dari masalah yang mereka hadapi. Diberikan pelatihan yang bermanfaat bagi masyarakat dan membantu mempromosikan hasil keterampilan masyarakat dan hasil UP2K .Hal ini sejalan dengan pendapat masyarakat yaitu sebagai berikut :" Segeralah dibentuk Posyandu model disetiap daerah, supaya masyarakat lebih bisa merasakan manfaat dari posyandu tersebut. Dan mulai dibentuk Forum Komunikasi KDRT agar kita bisa konsultasi segala macam secara bebas dan tidak malu kalo cerita kepada orang yang dipercaya, ada rasa aman yang dirasakan oleh korban saat bercerita karena mereka malah malu untuk bercerita apa yang telah mereka alami kepada orang lain karena itu aib bagi mereka. Untuk menambah penghasilan 
diharapkan diadakan pelatihan keterampilan untuk masyarakat. Kami pun perlu wadah yang bisa menampung produk-produk hasil UP2K, karena bingung kalo mau bikin juga dijualnya dimana, pengemasannya bagaimana, bentuknya bagaimana, karena tidak semua orang yang ikut pelatihan, hanya orang-orang tertentu saja." Dalam hasil wawancara diatas dapat ditarik kesimpulan, bahwa penyokongan dalam proses pemberdayaan masyarakat melalui gerakan pemberdayaan dan kesejahteraan keluarga dinilai belum berjalan dengan optimal, disebabkan oleh kurangnya pembinaan dan tidak adanya tempat konseling sebagai wadah tempat curhat korban segala kriminalitas yang terjadi dimasyarakat, dan diharapkan masyarakat langsung dapat penanganan dari masalah yang dihadapi. Selain itu Masyarakat diharapkan diberikan pelatihan pengemasan produk makanan yang bersih dan halal dan pelatihan keterampilan pemanfaatan dari bahan-bahan bekas Sehingga masyarakat bisa lebih produktif dan mendapatkan tambahan penghasilan walau mereka hanya sebagai ibu rumah tangga biasa.

\section{Pemeliharaan}

Pemeliharaan yaitu memelihara kondisi kondusif agar tetap terjadi keseimbangan distribusi kekuasaan antara berbagai kelompok masyarakat. Pemberdayaan harus mampu menjamin keseimbangan dan keselarasan yang memungkinkan setiap orang memperoleh kesempatan usaha. Peningkatan kemampuan dalam membangun dan mempertahankan jaringan dengan berbagai sistem. Jaringan ini sangat penting dalam menyediakan dan mengembangkan berbagai akses terhadap sumber dan kesempatan bagi peningkatan keberdayaan masyarakat. Adapun hasil wawancara dengan Sekretaris sebagai berikut : "Gerakan PKK bersifat fleksibel, karena PKK harus bekerjasama dengan semua pihak terkait dan semua kalangan sehingga di dalam diri PKK itu pun harus kompak dan saling berkejasama, tidak saling menjelekan dan menjatuhkan. Gerakan PKK harus bisa mengikuti Program-program OPD terkait, harus bisa berkoordinasi dengan Kader dan Masyarakat. Sehingga jika tidak ada kekuatan didalam diri PKK sendiri semua tidak akan berhasil. Sesuai dengan fungsi manajemen yaitu Perencanaan, Pengorganisasian, Pelaksanaan dan Pengendalian, didalam Gerakan PKK pun harus memilikinya, karena jika fungsi manajemen itu tidak berjalan maka tidak akan tercapainya tujuan yang efektif dan efisien. Kekompakan antar pengurus PKK dan Kader diharapkan bisa memberikan kemajuan bagi PKK kedepannya, sehingga tercapainya kemandirian masyarakat sesuai dengan harapan yang ingin dicapai. Dukungan ketua TP.PKK pun mempengaruhi kinerja bawahannya, jika ketuanya semangat dan aktif biasanya bawahnya ikutan semangat dan aktif. Sebaliknya jika ketuanya tidak aktif biasanya bawahnya pun seperti itu tidak mau aktif. Kebiasaan yang sering terjadi adalah apabila ketua TP.PKK diganti atau habis masa baktinya, pengurus pun diganti semua oleh ketua yang baru dan buku-buku administrasi pun di ambil semua oleh ketua yang lama. Kebiasan itu yang sulit untuk dihilangkan. " Berdasarkan hasil wawancara dapat dijelaskan bahwa TP.PKK harus menjalankan fungsi manajemen menurut George $\mathrm{R}$ Terry yaitu Planning, Organizing, Actuating and Controling. Sehingga terjadi kekompakan dan adanya kerjasama di dalam organisasi PKK tersebut. Budaya Organisasi pun sangat penting untuk digunakan oleh TP.PKK, karena Budaya Organisasi menurut Robbins adalah 
sebuah sistem makna bersama yang dianut oleh masing-masing anggota yang membedakan sebuah organisasi dengan organisasi yang lain. Dan budaya organisasi juga berfungsi sebagai penentu arah organisasi. Gerakan PKK harus bersifat fleksibel, karena PKK akan bekerjasama dan berkoordinasi dengan semua pihak terkait dan semua kalangan. Ditambah dengan keaktifan ketua pun sangat mempengaruhi kinerja pengurusnya. Selanjutnya peneliti mewawancarai Kader yaitu sebagai berikut : "Diharapkan Pengurus PKK tidak berganti-ganti dengan berbagai alasan sehingga kita mudah untuk berkonsultasi tentang kegiatan. Pengurus sering berganti-ganti sehingga pengetahuan mereka pun belum banyak dan tidak mengetahui secara benar tentang gerakan PKK. Bagaimana mau maju kalo pengurus selalu berganti-ganti. Pengaruh keaktifan dan semangat ketua PKK untuk terjun ke lapangan pun sangat mempengaruhi semangat kerja pengurus dan Kader untuk terjun ke lapangan. Kita bekerja dengan sukarelawan "

Berdasarkan hasil wawancara diatas dapat dijelaskan bahwa untuk mengoptimalkan proses pemberdayaan masyarakat diperlukan kekompakan antar Ketua. Pengurus, Kader dan Masyarakat, jika itu telah terjadi maka akan memperkuat gerakan PKK apalagi ditambah dengan dukungan dari pemerintah, maka semakin kokoh saja gerakan PKK. Hal ini sejalan dengan pendapat masyarakat yaitu sebagai berikut :" Kinerja kader akan meningkat, jika ada dukungan dari banyak pihak. Salah satunya apalagi kalo ketua PKK aktif dan peduli kepada kegiatan PKK maka akan berjalannya kegiatan PKK dan sebaliknya kalo ketua PKK tidak aktif dan tidak peduli kepada kegaiatan PKK maka semakin tidak berjalannya kegiatan PKK. Para Kader biasanya sangat semangat mendedikasikan dirinya dalam kegiatan PKK, sehingga terkadang sampai sudah berumur pun mereka masih menjadi kader." Dalam hasil wawancara diatas dapat ditarik kesimpulan, bahwa pemeliharaan dalam proses pemberdayaan masyarakat melalui gerakan pemberdayaan dan kesejahteraan keluarga dinilai belum berjalan dengan optimal, disebabkan oleh aktif tidaknya ketua sangat mempengaruhi kinerja pengurusnya, ditambah seringnya berganti-ganti pengurus TP.PKK dengan berbagai macam alasan, dan kurangnya respon dari pemerintah setempat membuat Gerakan TP.PKK tidak ada kemajuan setiap tahunnya. Fungsi manajemen dan budaya organisasi yang baik, harus dimiliki oleh gerakan PKK, karena jika itu tidak berjalan dengan baik maka tidak akan tercapainya tujuan yang efektif dan efisien . Berdasarkan hasil wawancara diatas dijelaskan bahwa dampak dalam Proses Pemberdayaan Masyarakat melalui Gerakan Pemberdayaan dan Kesejahteraan Keluarga masih belum memberikan dampak yang optimal bagi semua kalangan. Dari beberapa hasil wawancara diatas tentang Pemungkinan, Penguatan, Perlindungan, Penyokongan dan Pemeliharaan dalam Proses Pemberdayaan Masyarakat melalui Gerakan Pemberdayaan dan Kesejahteraan Keluarga di nilai belum optimal. Hal tersebut dinilai berdasarkan sudut pandang peneliti dan hasil wawancara dari narasumber dimana temuan dilapangan mengenai dampak dari Pemberdayaan Masyarakat belum sesuai dengan teori yang dikemukakan oleh Edi Suharto. 


\section{Kesimpulan}

Berdasarkan hasil penelitian dan pembahasan terhadap permasalahan yang telah dikemukakan sebelumnya, dapat ditarik kesimpulan sebagai temuan penelitian yaitu bahwa Proses Pemberdayaan Masyarakat melalui Gerakan Pemberdayaan dan Kesejahteraan Keluarga diukur berdasarkan Strategi Pemberdayaan menurut (1997), sebagai berikut :

1. Pemungkinan, berdasarkan sudut pandang peneliti dan hasil wawancara dimana pengembangan potensi yang ada dengan memperbanyak pelatihan-pelatihan keterampilan, sosialisasi-sosialisasi sehingga masyarakat bisa merubah pola pikir dan cara pandang mereka tentang manfaat potensi yang ada di masyarakat. Tetapi banyak kendala yang harus dihadapi seperti SDM yang kurang memadai (faktor usia, faktor pendidikan,dan faktor kebiasaan), anggaran yang terbatas, kurang dukungan dari OPD-OPD terkait dan pejabat setempat

2. Penguatan, penambah pengetahuan masyarakat dipengaruhi oleh pengaruh kader yang mensosialisasikan kepada masyarakat tentang berbagai informasi seperti pentingnya pendidikan, kesehatan dan masih banyak lagi. Penerimaan informasi yang diterima masyarakat dipengaruhi oleh pengetahuan yang dimiliki, dipengaruhi bagaimana cara penyampaian kader dari cara bicara, mimik wajah dan postur tubuh kader dan cara mengajak masyarakat untuk hidup lebih baik lagi. Karena diharapkan dengan ini bisa mengubah cara pandang, pola pikir dan bisa merubah kebiasaan masyarakat Apalagi sekarang zaman millenial sehingga diharapkan para kader diharapkan bisa mengikuti teknologi, jangan terlalu gagap teknologi.

3. Perlindungan, masih kurangnya sosialisasi atau penjelasan tentang segala macam kriminalitas yang mengincar kita semua dan tidak mengetahui tindakan-tindakan kriminalitas yang terjadi dimasyarakat. Pelaksanaan ketahanan keluarga belum berjalan secara optimal, belum adanya tempat untuk konsultasi masyarakat, dan kurangnya dukungan dari Pejabat Setempat.

4. Penyokongan, kurangnya pembinaan dan tidak adanya tempat konseling sebagai wadah tempat curhat korban segala kriminalitas yang terjadi dimasyarakat, dan diharapkan masyarakat langsung dapat penanganan dari masalah yang dihadapi. Selain itu Masyarakat diharapkan diberikan pelatihan pengemasan produk makanan yang bersih dan halal dan pelatihan keterampilan pemanfaatan dari bahan-bahan bekas Sehingga masyarakat bisa lebih produktif dan mendapatkan tambahan penghasilan walau mereka hanya sebagai ibu rumah tangga biasa.

5. Pemeliharaan, disebabkan oleh aktif tidaknya ketua sangat mempengaruhi kinerja pengurusnya, ditambah seringnya berganti-ganti pengurus TP.PKK dengan berbagai macam alasan, dan kurangnya respon dari pemerintah setempat membuat Gerakan TP.PKK tidak ada kemajuan setiap tahunnya. Fungsi manajemen dan budaya organisasi yang baik, harus dimiliki oleh gerakan PKK, karena jika itu tidak berjalan dengan baik maka tidak akan tercapainya tujuan yang efektif dan efisien.

1. Diharapkan OPD terkait bekerjasama dengan TP.PKK bisa lebih memperbanyak pelatihan-pelatihan dan keterampilan, sehingga diharapkan masyarakat 
menambah pengetahuan dan bisa memanfaatkan segala potensi yang ada di sekitarnya.

2. Diharapkan OPD terkait bisa meningkatan anggaran untuk TP.PKK agar bisa mengoptimalkan penyuluhan atau sosialisasi kepada masyarakat.

3 Adanya koordinasi antara TP.PKK, POLRES, P2TP2A, dalam pembinaan masyarakat untuk menerangkan segala tindakan-tindakan kriminalitas yang ada di sekitar kita dan memberikan solusi disetiap kejadian

4. Semakin diperbanyak posyando Model, disetiap daerah karena dengan adanya posyandu model diharapkan segala masalah yang ada di masyarakat dapat tertangani. Adanya Forum Komunikasi KDRT Sebagai tempat Konseling bagi masyarakat.

5. Ada himbauan dari TP.PKK kepada Istri Kepala Daerah baik kecamatan atau desa yang baru jangan mengganti semua Pengurus kecuali yang kurang atau tidak aktif

\section{Referensi}

Agustino, Leo. 2006.Dasar-Dasar Kebijakan Publik. Bandung: CV Alfabeta.

BPS, 2016, Data Kecamatan Pamanukan, 2016

Hikmawan, M. D. (2017a). Pluralisme Demokrasi Politik di Indonesia. Journal of Governance, 2(2), 223-247.

https://doi.org/http:/ /dx.doi.org/10.31506/jog.v2i2.2678

Hikmawan, M. D. (2017b). Politik Perbedaan: Minnoritas dalam Implementasi

Kebijakan. Journal of Indonesian Public Administration and Governance Studies (JIPAGS), 1(1), 88-98.

Hikmawan, M. D., \& Hidayat, R. (2016). Depoliticisation of Public Issue : Low

Degree of Government ' S Democratic Legitimacy. Journal of Governance, 1(1),

23-37. https://doi.org/http://dx.doi.org/10.31506/jog.v1i1.1311

Irianto, I, 2012, Reposisi PKK: Fungsi Pembentukan dan Pengembangan Potensi. Bandung: Wacana Gelora Cipta

Jones, Charles O. 1991.Pengantar Kebiiakan Publik. Nashir Budiman Jakarta: PT Raja Grafindo Persada.

Kumolo, Erni Gunarti Tjahjo, 2015. Hasil Rakernas VIII PKK Tahun 2015, Jakarta : TP.PKK

Laporan Tahunan TP.PKK Kabupaten Subang tahun 2017

Mardikanto,Totok Prof.Dr.Ir,M.S. dan Soebiato Poerwoko, Dr.Ir.H, M.Si. 2012. Pemberdayaan Masyarakat Dalam Perspektif Kebijakan Publik. Bandung: CV Alfabeta 
Moleong, Lexy J. 2006. Metodologi Penelitian Kualitatif. Bandung: PT Remaja Rosdyakarya

Pasolong, Harbani. 2008. Teori administrasi Publik. Alfabeta. Bandung

Peraturan Presiden Republik Indonesia Nomor 99 Tahun 2017 tentang Gerakan Pemberdayaan dan Kesejahteraan Keluarga,

Permendagri Nomor 1 Tahun 2013 tentang Pemberdayaan Masyarakat Melalui Gerakan Pemberdayaan dan Kesejahteraan Keluarga.

Pratama, Anandita Fitriani. 2009. Peluang Usaha disekitar kita. Bandung: CV.Dua Usaha Muda

Siagian, Sondang P. 1997. Organisasi, Kepemimpinan dan Perilaku Administrasi. Jakarta: PT. Toko Gunung Agung.

Silalahi, Ulbert. 2007. Studi Tentang llmu Administrasi: Konsep, Teori dan Dimensi. Sinar Baru Algensindo. Bandung.

Suharto Edi, 2004, Membangun Masyarakat Memberdayakan Rakyat. Bandung: Refika Aditama .

Sulistiyani Ambar Teguh, 2017, Kemitraan dan Model-model Pemberdayaan, Yogyakarta : Gava Media Yogyakarta

Sulistiyani, Ambar Teguh dan Rosidah, 2003, Manaiemen Sumber Daya Manusia, Graha Ilmu: Yogyakarta.

Soegiyono. 2002. Metode Penelitian Administrasi. Bandung: Alfabeta.

Usman, Husaini. 2011. Metode Penelitian Sosial, Jakarta: Bumi Aksara Jakarta

Wahab S.2008. Pengantar Analisis Kebijakan Publik. Jakarta:Rineke Cipta.

Widodo, Joko. 2006. Analisis Kebijakan Publik konsep dan aplikasi. Surabaya : Bayu Media.

Widiyanto, A., Hikmawan, M. D., \& Riswanda, riswanda. (2019). JSPG: Journal of Social Politics and Governance Implementasi Rencana Aksi Nasional Bela Negara Berdasarkan Instruksi Presiden Nomor 7 Tahun 2018 Oleh Dewan Ketahanan Nasional Republik Indonesia. Journal of Social Politics and Governance, 1(2), 95-115. 